\title{
The Effect of Suckermouth Catfish (Pterygoplichthys sp.) Population Explosions on the Effectiveness of Fishing and the Sustainability Status of Sidenreng Lake Waters
}

\author{
Hasrianti ${ }^{* 1}$ Surianti $^{1}$ A. Rini Sahni Putri ${ }^{1}$ Damis ${ }^{1}$ Resky Amalia Rajab ${ }^{2}$ \\ Abd Hakim Akbar ${ }^{3}$ \\ ${ }^{1}$ Department of Fisheries Science, Faculty of Science and Technology, Muhammadiyah University of Sidenreng \\ Rappang, Indonesia \\ ${ }^{2}$ Kupang Polytechnic Marine and Fisheries, East NusaTenggara, Indonesia \\ ${ }^{3}$ Institute of Agricultural Technology, South Sulawesi, Indonesia \\ * Corresponding author. Email: anthiafnan@outlook.com
}

\begin{abstract}
The suckermouth catfish is one type of fish species which is an invasive species. The occurrence of suckermouth catfish population explosion in the waters of Lake Sidenreng had an impact on the sustainability of marine biodiversity as well as an impact on the production of fishermen's catch. This study aims to determine the effect of suckermouth catfish population explosion on the effectiveness of fish filling and the sustainability status of Sidenreng Lake water management. This research was conducted for three months, from June to August 2020 in Teteaji Village and Wette'e Village, Sidenreng Rappang Regency. This study aims to determine the effect of fishing effectiveness and the status of the sustainability of the management of Lake Sidenreng. The effect of population explosion on the effectiveness of fishing was analyzed descriptively based on a comparison of the production of moderate catches on the sustainability status of Sidenreng Lake management using the RAPFISHMDS (Rapid Appraisal for Fisheries-Multidimensional Scaling) method. Based on the analysis of the suckermouth catfish population explosion in Sidenreng Lake, it has an impact on capture fisheries activities in Lake Sidenreng, namely on fishing gear, fishing operations and production of catches. The status of the sustainability of Sidenreng Lake management based on the RAPFISH MDS sustainability analysis from all dimensional aspects (ecological, economic, social and technological dimensions) shows that the sustainability status of Lake Sidenreng is 51.12 including the fairly sustainable category.
\end{abstract}

Keywords: suckermouth catfish, invasive species, sustainability status, Sidenreng Lake waters

\section{INTRODUCTION}

Lake Sidenreng is one of the freshwater ecosystems that has great potential in South Sulawesi with an area of $\pm 4,753.30 \mathrm{Ha}$ which functions as a fish producer which is used by fishermen who live around Lake Sidenreng to meet animal protein needs and increase household income fisherman.

Various types of fish in Sidenreng Lake are starting to become extinct due to fishing activities and daily activities of the people around the lake. Some of the destructive activities are the use of nonselective fishing gear, use of electricity (strom), use of poison and explosives, disposal of household and agricultural waste, weed growth, and silting [1].

Suckermouth catfish is one type of fish species that has been found in Sidenreng Lake in recent years. Suckermouth catfish (Pterygoplichthys spp.), is a foreign fish originating from South America and Central America [2]. The suckermouth catfish species in Sidenreng Lake have an impact on the production of fishermen's catch and the diversity of types of fish caught. The existence of suckermouth catfish is a threat to the population of local fish species other than because these species are resistant to polluted environmental conditions and have the ability to adapt quickly and can survive with a high level of tolerance to unfavorable environmental conditions 
such as poor water quality. low and polluted waters [3], suckermouth catfish also prey on small fish and fish eggs [4] so that it affects the diversity of fish resources in Lake Sidenreng.

Sustainable fisheries are aimed at creating a balance between the health of the lake ecosystem and human health as a resource user. The aspects studied in sustainable fisheries are ecological, economic, social, and technological aspects [5]. The principle of sustainable fisheries has four aspects of ecological dimensions (target catch species. Catch disposal (suckermouth catfish), level of fish resource utilization, size of fish caught, fish diversity, and location of fishing grounds), economic dimension aspects (catch per trip. fishermen per trip, investment, average income and marketing), aspects of the social dimension (level of education, environmental knowledge, the role of fishermen for sustainability, participation of family members, access to resources, other work alternatives), and aspects of the technological dimension (length of operation, Damage to nets (impact of suckermouth catfish on fishing gear), handling of fish on board, use of tools, selectivity, size of vessel). This research was conducted to determine the effect of suckermouth catfish population explosion on the effectiveness of fishing (fish catch production before and after the suckermouth catfish population explosion) and the sustainability of Sidenreng Lake fisheries management.

\section{MATERIALS AND METHODS}

This research was conducted from June to August 2020 in Lake Sidenreng, namely in Teteaji Village, Tellu Limpoe District and in Wette'e Village, Panca Lautang District, Sidenreng Rappang Regency. This research is descriptive quantitative with the type of data collected including primary and secondary data and qualitative and quantitative in nature. The data collected is based on the attributes of sustainable Lake Sidenreng including the ecological, social, economic and technological dimensions. The following map of the research location is presented in the image below.

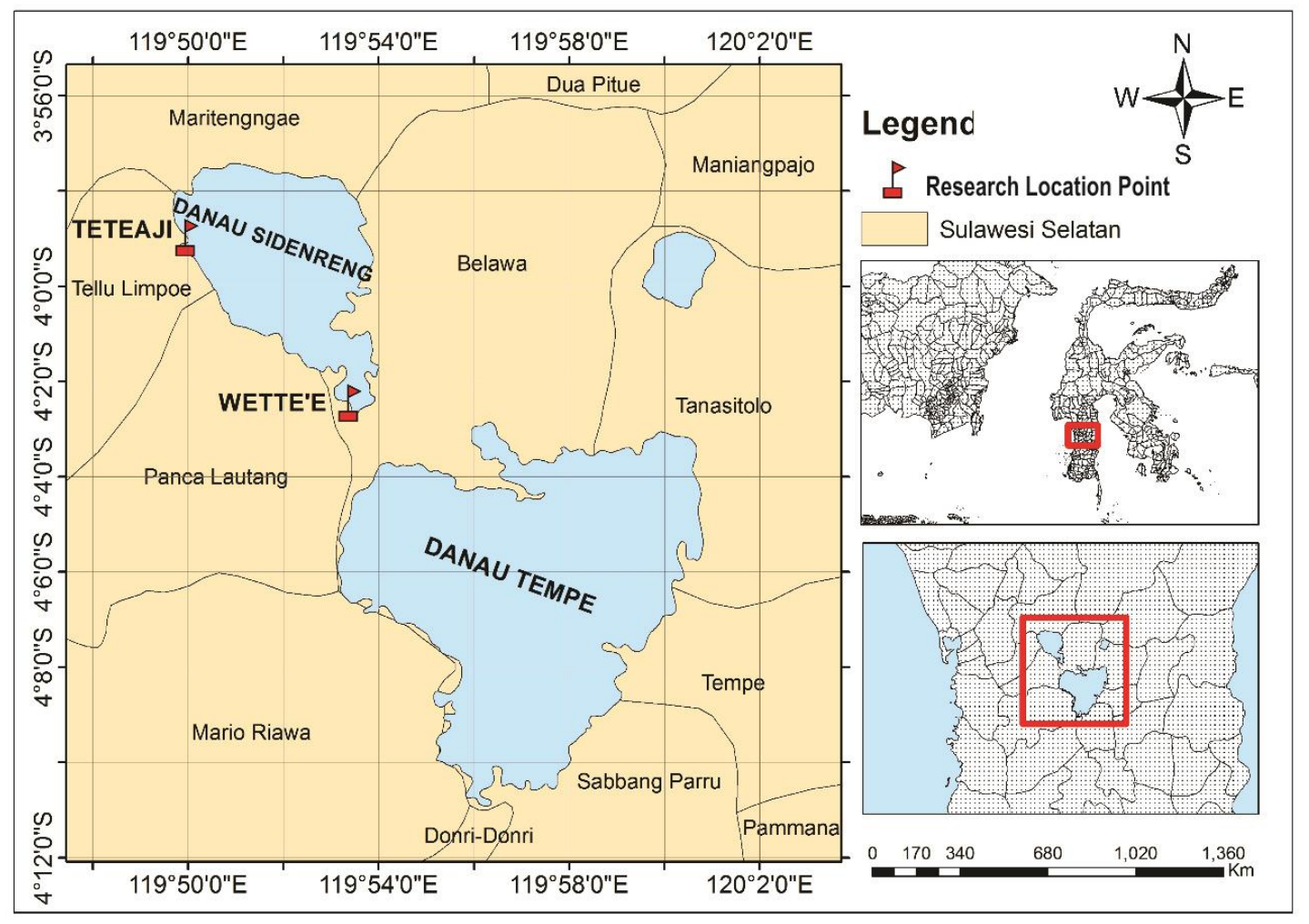

Figure 1. Map of the Research Location

The effect of population explosion on the effectiveness of fishing was analyzed descriptively based on the comparison of the catch production, while to assess the sustainability status of Lake Sidenreng after the presence of suckermouth catfish fish, using RAPFISH MDS (Rapid Appraisal for Fisheries Muldimensional Scaling) developed by the University of British Columbia for evaluate fisheries in a multidisciplinary manner [6]. The RAPFISH MDS method includes sustainability status, 
sensitivity analysis (Leverage analysis), and Monte Carlo analysis to account for uncertainty [7] based on ecological, social, economic, and technological dimensions. The position of sustainability status will be based on categories in the $0-100 \%$ range (Table 1 ).

Table 1. The Category of The Sustainability Index Scales [8]

\begin{tabular}{ccc}
\hline No & Index Scale (\%) & Category \\
\hline 1 & $0.00-25.00$ & Poor (unsustainable) \\
2 & $25.01-50.00$ & Less (less sustainable) \\
3 & $50.01-75.00$ & Quite (fairly sustainable) \\
4 & $75.01-100.00$ & Good (very sustainable)
\end{tabular}

The standard category of stress value for RAPFISH analysis is shown in Table 2 below

Table 2. Standard categories of stress values [9].

\begin{tabular}{cc}
\hline Stress (Percent) & Goodness of Fit \\
\hline 20 & Poor \\
10 & Fair \\
5 & Good \\
2.5 & Excelent \\
\hline 0 & Perfect \\
\hline
\end{tabular}

\section{RESULT AND DISCUSSION}

\subsection{The Effect of suckermouth catfish on the Effectiveness of Catching Fish}

The population explosion of suckermouth catfish has an impact on fishing activities in Lake Sidenreng both on fishing gear, the fishing process and the catch obtained. There are several impacts, including:

1. Fishing gear operated by fishermen, suckermouth catfish tends to damage fishermen's nets,

2. In the fishing process, the presence of suckermouth catfish adds to the hauling time of fishing operations due to the release of suckermouth catfish from the nets which are quite difficult to remove, so it takes time, which in turn increases the operating time.

3. The main catch (target catch) of fishermen tends to decrease and the waste catch (suckermouth catfish) of fishermen tends to increase.

The main catch (target species) from fishing gear operated by fishermen in Sidenreng Lake are tilapia and Tawes fish with bycatch namely snakehead fish, catfish, carp and betutu fish etc. The average catch of target fish (tail) is 150 heads, while the catch of gill nets is 175 heads per fishing trip. The comparison of the average number (tail) of the catch is presented in Figure 2 below:

Comparison of the amount of the waste catch and the main catch which shows the average catch of the waste is higher than the main catch proves that the presence of suckermouth catfish in Sidenreng Lake waters has become a threat to the population of local fish species that exist. This is because suckermouth catfish can have a high adaptability, making it possible to become pests in certain waters [10].

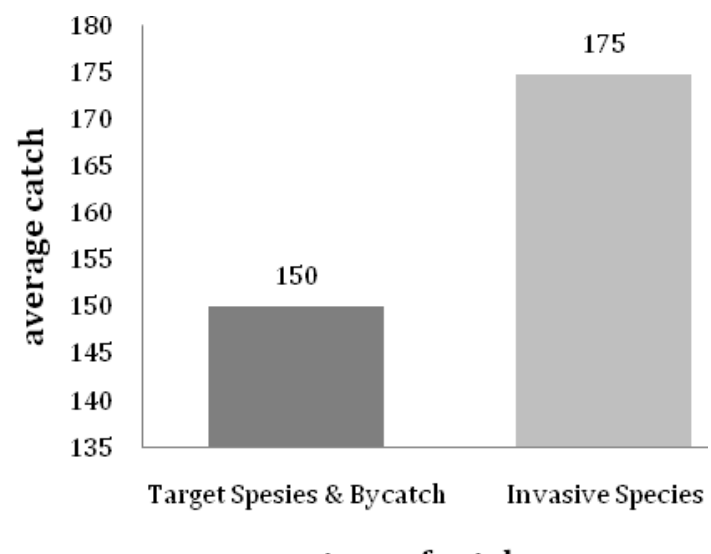

\section{type of catch}

Figure 2. Average catch ratio (tail) per fishing trip

The proportion of the main catch of gill nets that has decreased and the catch of waste (suckermouth catfish) which has increased is thought to have been triggered by competition and eating habits of suckermouth catfish that eat fish eggs. Although the research was done by [11] informs that the ecological impact of suckermouth catfish (Pterygoplichthys sp.) is the disruption of the aquatic food chain due to excessive use (consumption) of benthic algae and detritus in the waters and a decrease in the number of native species (local aquatic fish) due to competition. and egg damage.

Types of fish caught in gill nets in Lake Sidenreng are presented in Figure 3. There are 6 types of fish that are often caught in nets. The average number (tail) of fish caught was based on the most dominant type and the most caught (main target), namely Silver Barb (Barbonymus goniono Bleeker, 1850) and nile tilapia (Oreochromis niloticus), besides that, several other species were also caught such as snakehead murrel (Channa striata), tank goby (Glossogobius sp.), carp (Cyprinus carpio), sutchi catfish (Pangasius sp.) and marble goby (Oxyeleotris marmorata). 
Based on the diagram of the composition of fish species caught in the gill nets, it shows that the presence of suckermouth catfish fish (Pterygoplichthys sp.) has an impact on the diversity of fish caught by fishermen. This condition is the same as what happened in the Ciliwung River reported by [12], the population of suckermouth catfish fish that dominates the river waters so that several fish species that were easy to find, including benteur (Barbodes binotatus), Silver Barb (Barbonymus spp.) Are now difficult to obtain.

\section{Composition of Catch}

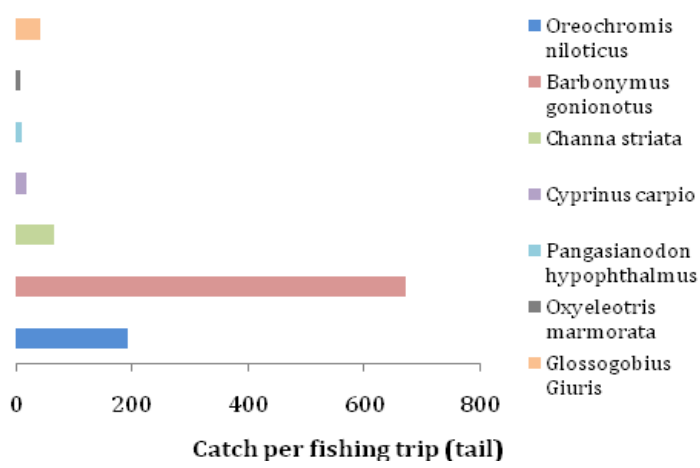

Figure 3. Composition of catch (tail) per fishing trip

\subsection{Sidenreng Lake Sustainability Status}

\subsubsection{The Ecological Dimension}

Based on the results of the analysis of the sustainability of Lake Sidenreng with an assessment of the ecological dimensions, all aspects of the assessment have an effect on the sustainability status which includes the target catch species. Catch of

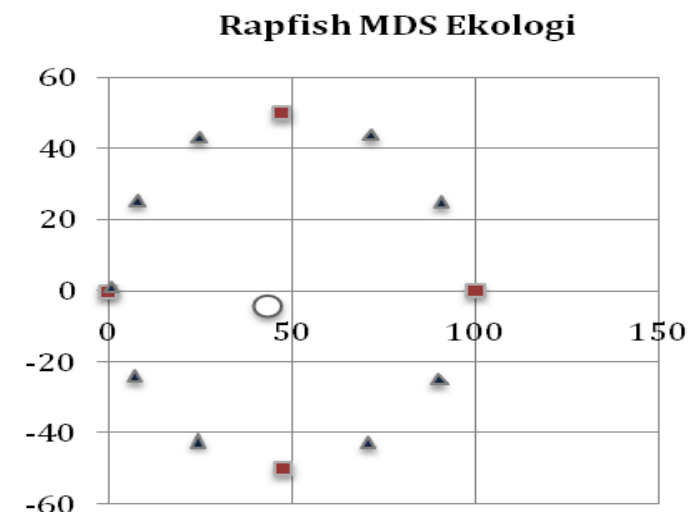

A waste (suckermouth catfish), level of fish resource utilization, size of fish caught, fish diversity, and location of fishing grounds affect the sustainability status so that it is in a less sustainable status with a sustainability index of 43.45 (Figure 4A). The test results with the application of the RAPFISH-MDS method show that the ecological sustainability index has a stress value of $15.71 \%$ which is in the fair category which means good [9]. The R2 value in the model is 0.94 or close to 1 , so it can be concluded that the analysis results can present the model well. The stress and R2 values indicate that the attributes used in the study are accurate in assessing the sustainability index of Lake Sidenreng in the ecological dimension.

Based on the sensitivity analysis, the attributes that have the largest value of change in Root Mean Square (RMS) are the attribute diversity of fish species by $3.11 \%$ and attributes of the captured waste by $2.90 \%$ (Figure $4 . b$ ) The decreasing diversity of fish species is the impact of the suckermouth catfish fish population explosion, Although based on previous research which states that the presence of suction mouth catfish in public waters is a separate threat to the local fish community in it. In addition, the impacts that can be caused by this type of fish include changes in the structure of the aquatic environment, disruption of the food chain, competition with endemic species in the use of important resources such as food and living space, changes in aquatic plant communities, and damage to fishing gear. gill net fishermen are increasing while the target catch (main catch) is decreasing due to the increasing population of suckermouth catfish from year to year.

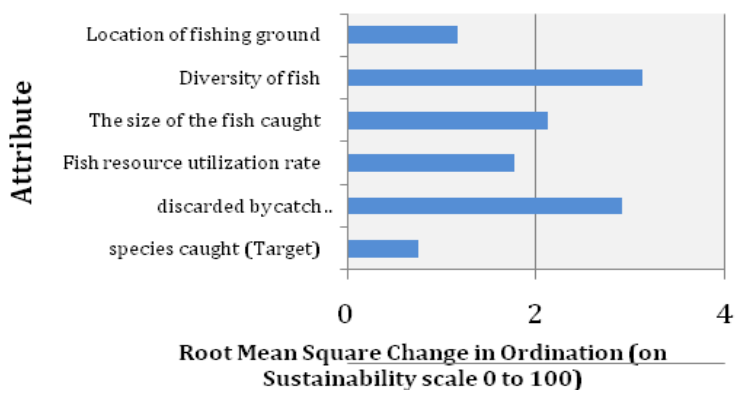

B

Figure 4. Sustainability index (A) and leverage analysis results (B) of the ecological dimension 
Although the research was done by [13] in his study stated that from 1985 to 2004 the catch of suckermouth catfish experienced a significant increase while the silver barb catches decreased.

\subsubsection{Economic Dimensions}

In the aspect of the economic dimension the aspects of the assessment consist of catch per trip. fishermen's income per trip, investment, average income and marketing. Based on the test results with the application of the RAPFISH-MDS method, the results of the economic dimension aspect assessment show a sustainability index of $54.53 \%$ (Figure 5A) with a fairly sustainable status. while the stress value of $15.72 \%$ which is in the fair category means good. The R2 value in the model is 0.94 or close to 1 , so it can be concluded that the analysis results can present the model well. The stress and R2 values indicate that the attributes used in the study are accurate in assessing the sustainability index of Lake Sidenreng in the economic dimension.

Based on the sensitivity analysis, the attribute that has the largest value of change in Root Mean Square (RMS) is the attribute of operational cost per trip of $5.7 \%$ (Figure 5B). The decrease in the catch of gill net fishermen in Lake Sidenreng is due to the increasing population of suckermouth catfish resulting in a decrease in fishermen's income while operating costs remain constant. This results in operating costs per trip having a higher value compared to other attribute values.

\section{RAPFISH Ordination}

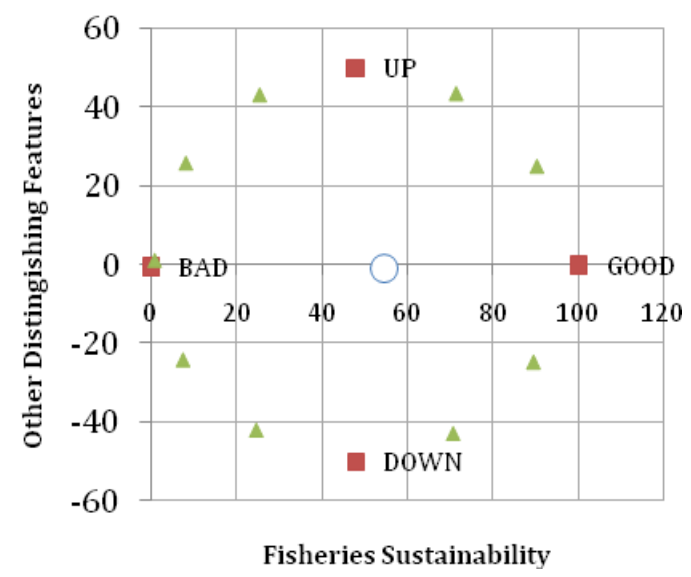

A

\subsubsection{Social Dimension}

Based on the results of the analysis of the sustainability of Lake Sidenreng with an assessment of the aspects of the social dimension in all aspects of the assessment, it affects the sustainability status which includes education level, environmental knowledge, the role of fishermen for sustainability, participation of family members, access to resources, other work alternatives that affect the sustainability status so that they are in unsustainable status with a sustainability index of 60.52 (Figure 6A). The test results with the application of the RAPFISH-MDS method show that the ecological sustainability index has a stress value of $15.98 \%$ which is in the fair category which means good. The R2 value in the model is 0.94 or close to 1 , so it can be concluded that the analysis results can present the model well. The stress and R2 values indicate that the attributes used in the study are accurate in assessing the sustainability index of Lake Sidenreng in the ecological dimension.

Based on the sensitivity analysis, the attribute that has the largest value of change in Root Mean Square (RMS) is the attribute of other job alternatives by $2.36 \%$ (Figure 6B). The lack of income of fishermen has resulted in some fishermen looking for other alternative livelihoods to meet fishermen's household needs.

\section{Leverage of Attributes}

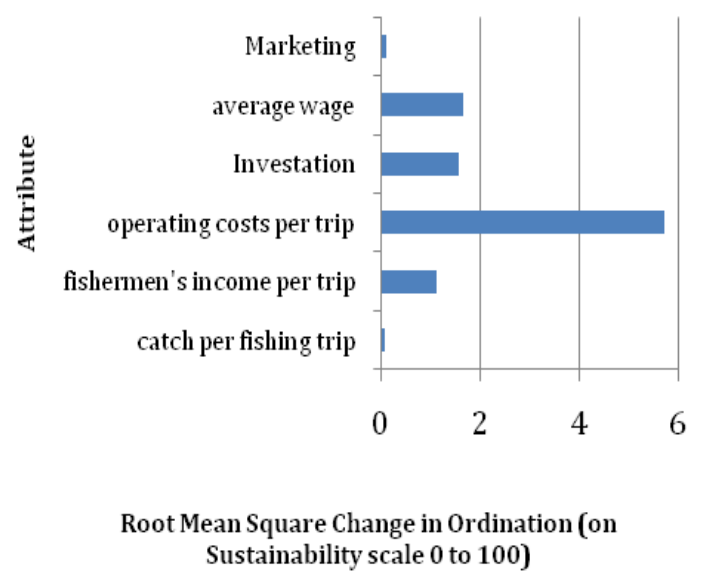

B

Figure 5. Sustainability index (A) and leverage analysis results (B) of the economic dimension 


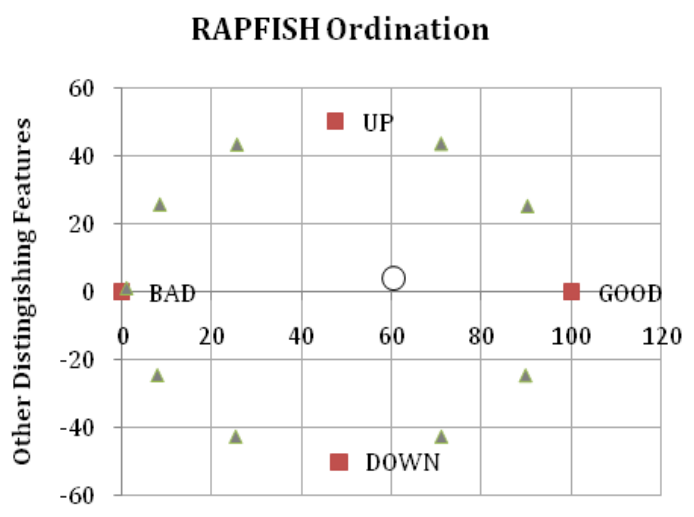

Fisheries Sustainability

\section{Leverage of Attributes}

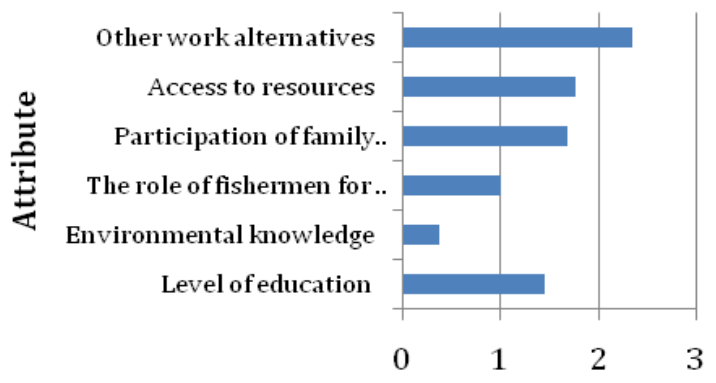

Root Mean Square Change in Ordination (on Sustainability scale 0 to 100 )

\section{A}

B

Figure 6. Sustainability index (A) and leverage analysis results (B) of the social dimension

\subsubsection{Dimensions of Technology}

In the aspect of the technological dimension, the aspects of the assessment consist of length of operation, damage to nets (impact of suckermouth catfish on fishing gear), handling of fish on board, use of tools, selectivity, size of the ship. Based on the test results with the application of the RAPFISHMDS method, the results of the assessment of aspects of the technology dimension showed a sustainability index of $45.98 \%$ (Figure 7A) with the status of Less (less sustainable). while the stress value of $15.37 \%$ which is in the fair category means good. The R2 value in the model is 0.94 or close to 1 , so it can be concluded that the analysis results can present the model well. The stress and R2 values indicate that the attributes used in the study are accurate in assessing the sustainability index of Lake Sidenreng in the economic dimension.

Based on the sensitivity analysis, the attribute that had the largest value of change in Root Mean Square (RMS) was the impact attribute of invasive fish species on fishing gear (damage to nets) by $3.6 \%$ (Figure 7B). Suckermouth catfish not only affects the production and income of fishermen but also causes damage to the nets which in turn has an impact on the effectiveness and efficiency of fishing in Sidenreng Lake. Then, based on the results of the RAPFISHMDS sustainability analysis of all dimensions (Figure 8), the sustainability status of Lake Sidenreng is 51.12 , including the fairly sustainable category.

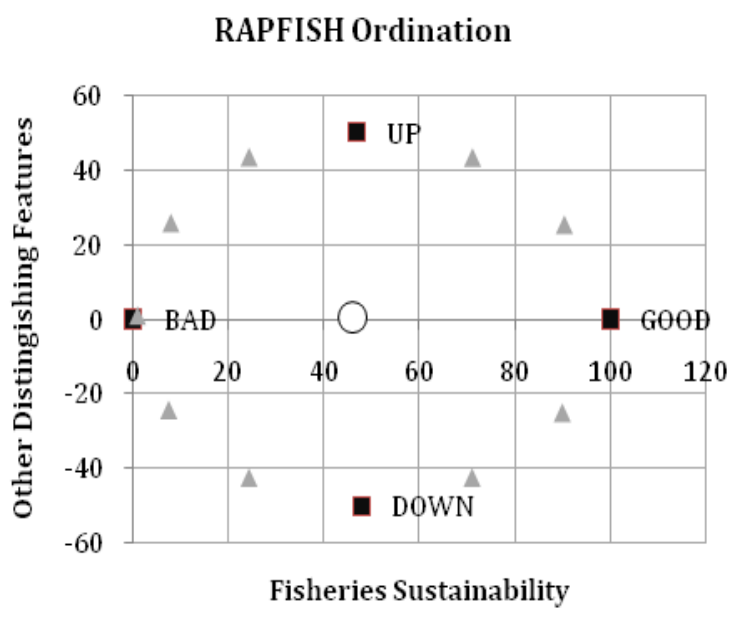

A

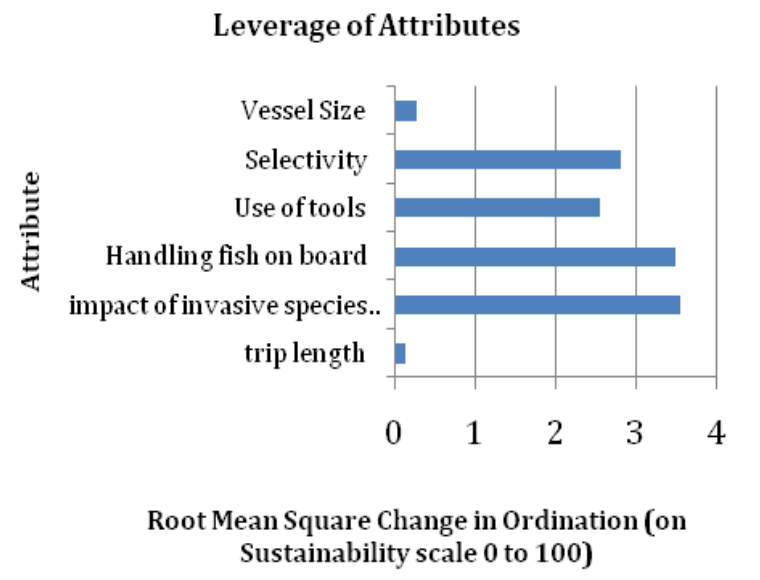

B

Figure 7. Sustainability index (A) and leverage analysis results (B) of the technology dimension 


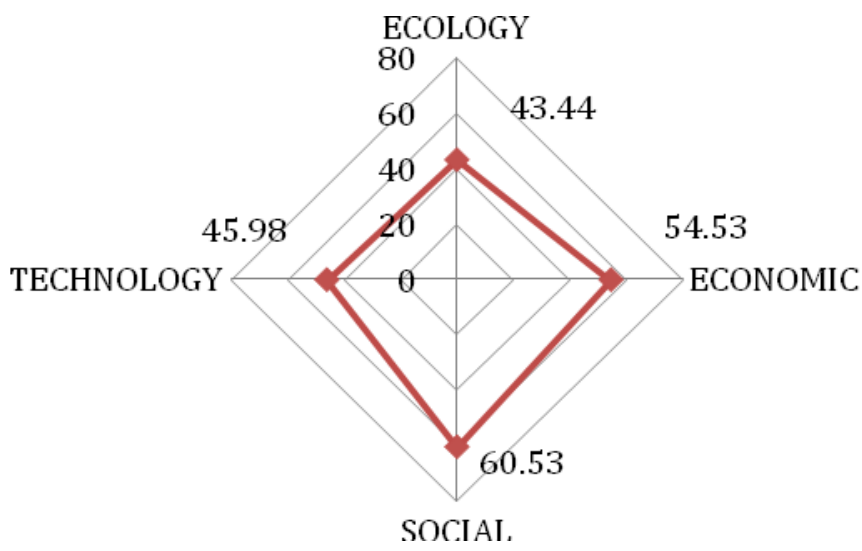

Figure 8. Kite Diagram of Sustainability Index of Four Dimensions

\section{CONCLUSION}

The presence of suckermouth catfish species in the waters of Lake Sidenreng, whose population from year to year continues to increase, there is an increase in the population explosion of suckermouth catfish. Based on the results of the impact study and the sustainability status of Lake Sidenreng, the results of this study are as follows:

1. The population explosion of suckermouth catfish in Lake Sidenreng has an impact on capture fisheries activities in Lake Sidenreng, namely on fishing gear, fishing operations and production of catches.

2. The status of the sustainability of Sidenreng Lake management based on the RAPFISH MDS sustainability analysis from all dimensional aspects (ecological, social, economic, and technological dimensions) shows that the sustainability status of Lake Sidenreng is 51.12, including the fairly sustainable category.

\section{REFERENCES}

[1] S.B. Andy Omar, Aspek reproduksi ikan nilem Osteochilus vittatus (Valenciennes, 1842) di Danau Sidenreng, Sulawesi Selatan, Jurnal Ikhtiologi Indonesia 10(2) (2010) 111-122. DOI: https://doi.org/10.32491/jii.v10i2.163. [In Bahasa Indonesia]

[2] Y.D. Aksari, D. Perwitasari, N.A. Butet. Kandungan logam berat $(\mathrm{Cd}, \mathrm{Hg}$, dan $\mathrm{Pb})$ pada Ikan Sapu-Sapu, Pterygoplichthys pardalis (Castelnau, 1855) di Sungai Ciliwung, Jurnal Iktiologi Indonesia 15(3) (2015) 257-266. DOI: https://doi.org/10.32491/jii.v15i3.61. [In Bahasa Indonesia]
[3] M. Tisasari, D. Efizon., C.P. Pulungan, Stomach content analysis of Pterygoplichthys pardalis from The Air Hitam River, Payung Sekaki District, Riau Province, Jurnal Online Mahasiswa 3(1) (2016) 1-14.

[4] R. Chaicana, S. Jongphadungkiet, Assessment of the invasive catfish Pterygoplichthys pardalis (Castelneu, 1855) in Thailand: Ecological impacts and biological control alternatives, Tropical Zoology 25(4) (2012) 173-182. DOI: https://doi.org/10.1080/03946975.2012.738494

[5] W.C. Valenti, J.M. Kimpara, B.L. Preto, Measuring aquaculture sustainability, World Aquaculture 42(3) (2011) 26-30.

[6] P. Kavanagh, Rapid appraisal fisheries (Rapfish) project rapfish software description (for Microsoft Excel), Fisheries Center Research Report University of British Columbia, Vancouver, Canada, 2001.

[7] P. Kavanagh, T.J. Pitcher, Implementing Microsoft Excel software for RAPFISH a technique for the rapid appraisal of fisheries status. Colombia: The Fisheries Center Research Report University of Colombia 12(2) (2004) 1-75. DOI: https://doi.org/10.14288/1.0074801

[8] M. Rosmiati, R. E. Putra, T. Lastini, E. Hernawan, Pujo, I. Rahmayunita, F. R. Maulana, F. Liesdiana, M. A. Nurdiansyah, A. Azis, Sustainability analysis of dairy horticulture integrated farming system, The Journal of Agricultural Sciences - Sri Lanka 15(2) (2020) 290-298. DOI: http://doi.org/10.4038/jas.v15i2.8813

[9] B. Simamora, AnalIsis multivariat pemasaran, Jakarta, PT. Gramedia Pustaka Utama, 2005. 
[10] G. Wahyudewantoro, Sapu-Sapu (Pterygoplichthys Spp.), Ikan pembersih kaca yang bersifat invasif di Indonesia, Warta Iktiologi 2(2) (2018) 22-28. [In Bahasa Indonesia]

[11] J.D.M. Knight, Invasive ornamental fish: a potential threat to aquatic biodiversity in Indian peninsular, Journal of Threatened Taxa 2(2) (2010)

$700-704$.

DOI: https://doi.org/10.11609/JoTT.o2179.7004

[12] R.K. Hadiaty, Diversitas dan hilangnya jenisjenis ikan di Sungai Ciliwung dan Sungai
Cisadane, Berita Biologi 10(4) (2011) 491-504. DOI:

https://doi.org/10.14203/beritabiologi.v10i4.767 [In Bahasa Indonesia]

[13] S. Adjie, A.D. Utomo, Hasil tangkapan beberapa jenis alat tangkap di Sungai Bengawan Solo, Palembang: penelitian balai riset perikanan perairan umum, Bawal Widya Riset Perikanan Tangkap 3(1) (2010) 33-44. DOI: http://dx.doi.org/10.15578/bawal.3.1.2010.33$\underline{44}$ [In Bahasa Indonesia] 